\title{
Survival and early growth of mixed forest stands installed in a Mediterranean Region: Effects of site preparation intensity
}

\author{
Felícia Fonseca $^{\mathrm{a}, *}$, Tomás de Figueiredo ${ }^{\mathrm{a}, 1}$, Afonso Martins ${ }^{\mathrm{b}, 2}$ \\ a Centro de Investigação de Montanha (CIMO), Escola Superior Agrária de Bragança, Campus de Sta Apolónia, Apartado 1172, 5301-855 Bragança, Portugal \\ b Universidade de Trás-os-Montes e Alto Douro, Apartado 1013, 5001-911 Vila Real, Portugal
}

\section{A R T I C L E I N F O}

Article history:

Available online xxx

\section{Keywords:}

Mediterranean Region

Pseudotsuga menziesii

Castanea sativa

Plantation

Mortality

Growth

\begin{abstract}
A B S T R A C T
In Mediterranean environments, availability of water and nutrients are the main factors limiting the success of afforestation. As part of a wider project, an experiment was established in Northeast Portugal, aiming at testing the effect of several site preparation techniques on plant survival and growth (height and diameter) in a newly installed mixed forest stand. Results presented regard plant response during 42 months after plantation. The experimental protocol consisted in seven treatments described by mechanical operations that rank soil disturbance intensity from none to high, set in plots of $375 \mathrm{~m}^{2}$, randomly distributed in three blocks, in different topographic positions (gentle slope plateau, moderate slope shoulder, and steep mid-slope). Pseudotsuga menziesii (PM) and Castanea sativa (CS) forest species were planted in a $4 \mathrm{~m} \times 2 \mathrm{~m}$ scheme and in alternate rows with 12 plants on each row per plot, summing up 72 plant per specie and treatment at start of the experiment. The results show that: (i) the highest mortality was observed immediately after the plantation and before the dry season, on the lowest intensity treatments; (ii) after the dry season, the highest mortality was also observed in treatments with the lowest intensity of soil disturbance, while the lowest values were found on the intermediate intensity treatments; (iii) during the experimental period, the effect of treatments on plant growth (height and diameter) was statistically significant; however, experimental results do not lead yet to a clear quantitative relationship between soil disturbance intensity due to site preparation and plant response under the conditions tested.
\end{abstract}

(C) 2011 Elsevier B.V. All rights reserved.

\section{Introduction}

In Mediterranean environments, availability of water and nutrients are the main factors limiting the success of afforestation (Daget, 1977; Rey, 1998; Ojasvi et al., 1999; Bocio et al., 2004). Afforestation programmes in Portugal have to take into account these soil and climatic constraints, as Mediterranean climate prevails in most of the territory (Ribeiro, 1986; Costa et al., 1998). In Portugal the success and productivity of most forest plantations is limited by poor soil conditions, namely a low root support capacity, which has negative effects on the amount of available water and nutrients. Soil preparation operations are therefore required before planting, using more or less intense tillage in order to increase soil depth, as well as water and nutrient availability, and, so, improving soil conditions for plant growth (Worrell and Hampson, 1997; Fisher and Binkley, 2000; Querejeta et al., 2001).

\footnotetext{
* Corresponding author. Tel.: +351 273303253/273303200; fax: +351 273325405 E-mail addresses: ffonseca@ipb.pt (F. Fonseca), amartins@utad.pt (A. Martins).

1 Tel.: +351273 303 200; fax: +351273325405

2 Tel.: +351259 35020; fax: +351259350480.
}

Several studies have been made on the effect of surface soil tillage using scarification and herbicide application for weeds and shrub control and improving root depth (McLaughlin et al., 2000; Archibold et al., 2000; Burgess and Wetzel, 2000; Wetzel and Burgess, 2001). However, there are only few references on the effect of deep tillage on soil properties and plant response (Fernandes and Fernandes, 1998; Fisher and Binkley, 2000; Querejeta et al., 2001; Martins and Pinto, 2004; Carlson et al., 2006). New studies are therefore necessary to improve our knowledge and to support decisions on best operation selection according to site conditions. The wide diversity of mechanical site preparation techniques that may be applied emphasizes the need for studies on newly installed forest stands, especially in areas where information is still limited, as it is particularly the case of the Mediterranean Region (Varelides and Kritikos, 1995). Furthermore, most studies are performed in adult stands, and so the installation phase is less understood, often lacking important components of the initial dynamics of these systems (Canham, 1989; Lieberman et al., 1989).

This paper aims at presenting and discussing data collected 42 months after plantation in an experiment carried out to study mortality and growth (height and diameter) of a mixed stand of

0378-1127/\$ - see front matter (c) 2011 Elsevier B.V. All rights reserved. doi:10.1016/j.foreco.2011.01.040 


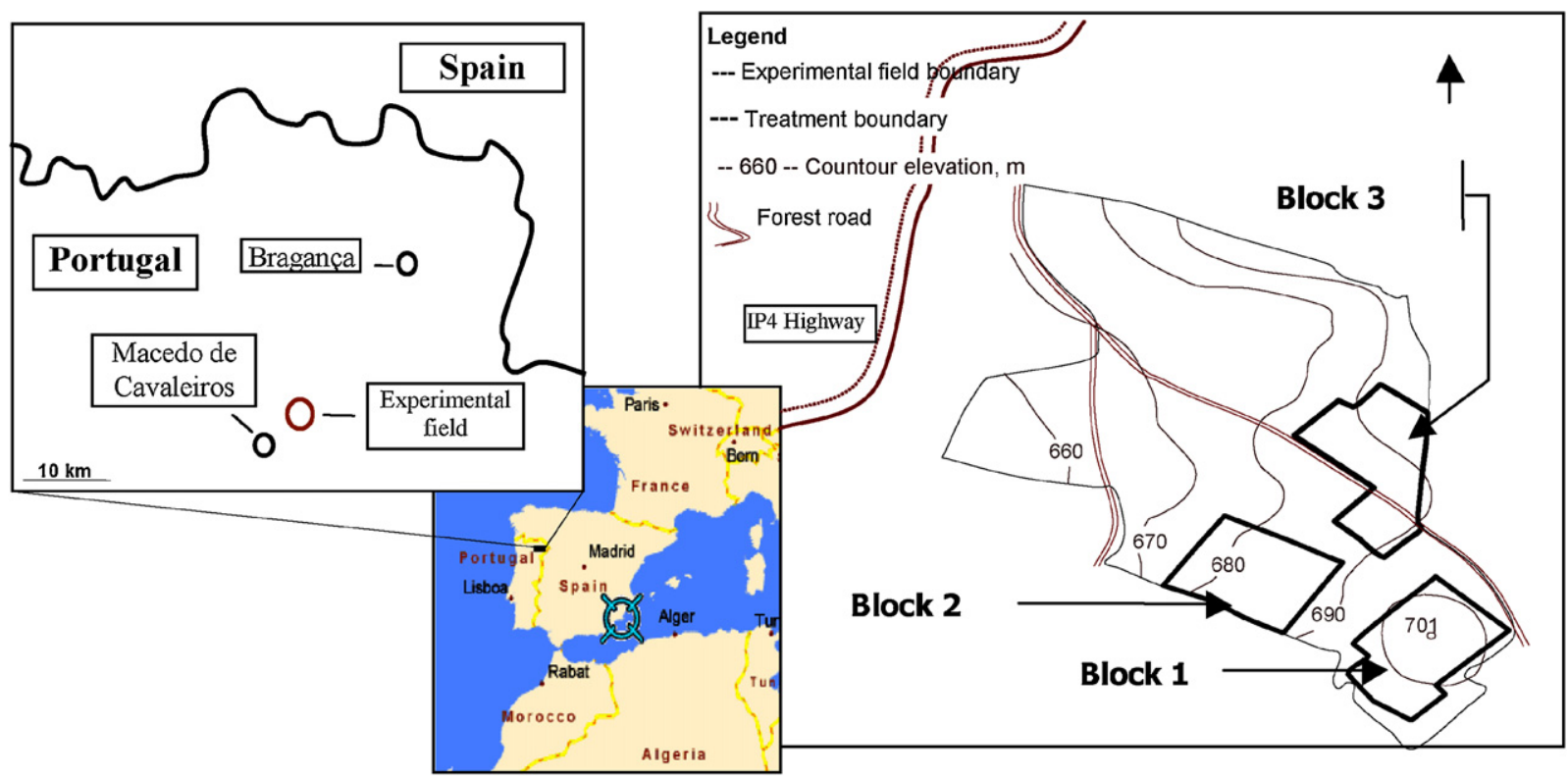

Fig. 1. Study area location.

Pseudotsuga menziesii and Castanea sativa, as affected by different mechanical operations performed for soil preparation.

\section{Materials and methods}

The experimental field was established near the municipality of Macedo de Cavaleiros, Northeast Portugal, at $41^{\circ} 35^{\prime} \mathrm{N}$ and $6^{\circ} 57^{\prime} \mathrm{W}$, local altitude ranging from 660 to $701 \mathrm{~m}$ (Fig. 1). Climate is Mediterranean, with $12^{\circ} \mathrm{C}$ mean annual temperature and $678 \mathrm{~mm}$ mean annual rainfall at Macedo de Cavaleiros (INMG, 1991). During the experimental period, annual rainfall was $665 \mathrm{~mm}$, monthly distributed according to Fig. 2, averages being computed from data recorded by an automatic rain gauge installed in the experimental site.

The experimental design consisted of six treatments representing different intensities of soil disturbance by mechanical operations for site preparation, randomly distributed on each one of three blocks, which cover the range of soil and topographic conditions commonly found in afforested areas in NE Portugal (Agroconsultores and Coba, 1991), described as follows: Block 1 on a gentle slope plateau ( $6 \%$ slope gradient), over sedimentary parent material Dystric Cambisols; Block 2 on a moderate slope shoulder (12\%); and Block 3 on a steep slope (22\%). Blocks 2 and 3

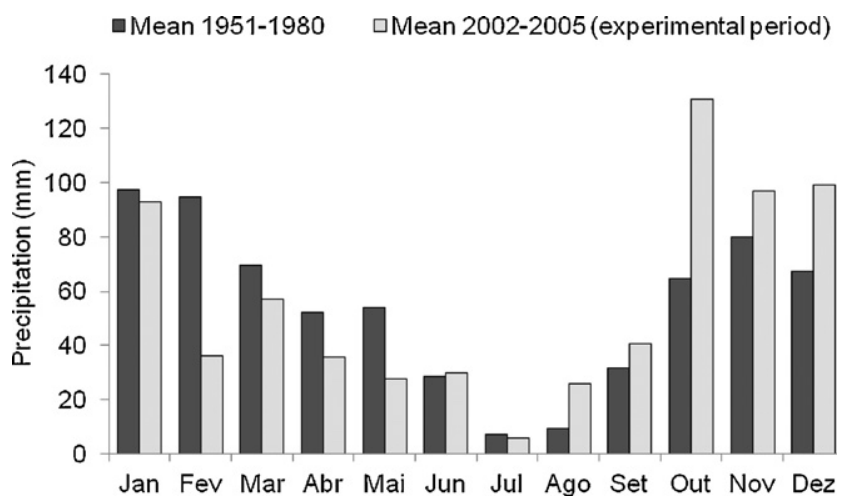

Fig. 2. Monthly average precipitation during the experimental period (2002-2005) and long term means (1951-1980). were installed in neighbouring west facing hillslopes, over schists, Dystric Leptosols (FAO/UNESCO, 1987; Agroconsultores and Coba, 1991). The treatments, described in Table 1, ranked from lowest (SMPC) to highest (RCLC) soil disturbance, induced by different soil preparation operations. Table 1 includes also a treatment without disturbance (TSMO), which corresponds to the original soil and is taken as a reference for comparison with the remainder treatments in what concerns the tillage effects on soil properties. Soil characteristics of experimental area prior to experiment installation (represented by TSMO, Table 1 ) were determined in previous work by the first author (Fonseca, 2005). Accordingly, soil texture varied between loam and sandy loam (63-73\% sand, $15-24 \%$ silt, 9-13\% clay), effective soil depth between 50 and $55 \mathrm{~cm}$, bulk density $(0-15 \mathrm{~cm})$ between 1.4 and 1.5 , organic carbon between 14 and $33 \mathrm{~g} \mathrm{~kg}^{-1}$, total nitrogen between 0.7 and $1.1 \mathrm{~g} \mathrm{~kg}^{-1}$, sum of exchangeable bases between 1.3 and $2.1 \mathrm{cmol}_{\mathrm{c}} \mathrm{kg}^{-1}$ and $\mathrm{pH}\left(\mathrm{H}_{2} \mathrm{O}\right)$ between 5.0 and 5.2 .

Plots $25 \mathrm{~m} \times 15 \mathrm{~m}$ in size (wider in contour) were taken as the experimental units in this study. A total of 21 plots were installed in the experimental field, accounting for 6 treatments plus one non planted reference in 3 blocks. The plots were separated by wide buffer belts of $3 \mathrm{~m}$. The species selected were $P$. menziesii $(P M)$ and $C$. sativa $(C S)$, planted in alternate contour rows, in a $4 \mathrm{~m} \times 2 \mathrm{~m}$ scheme (rows $\times$ plants in rows), each plot summing up two rows per specie, 12 plants per row in a total of 24 plants per species, and each treatment including 72 plants per species at the experiment start. The plantation was made by hand, in February 2002, using nursery seedlings, containerized in the case of $P M$ and bareroot in the case of $C S$.

For the evaluation of plant response, mortality was quantified according to the percentage of dead plants in the total in each treatment, at plantation, and in May (before the dry season, bds) and in September (after the dry season, ads) of 2002, 2003, 2004 and 2005. Plant growth was quantified as height and diameter at ground level, measured on all plants of each plot, at plantation, and after 12, 24, 27, 30, 36, 39 and 42 months, corresponding to four growing seasons. In the third and fourth growing season measurements were performed to further assess spring growth (24-27 and 36-39 month periods) and summer growth (27-30 and 39-42 months). SMPC and RCAV treatments were excluded from these measurements, because most of the plants died after plantation. As 
Table 1

Treatments representing the original condition and the six soil preparation operations performed before plantation.

\begin{tabular}{|c|c|}
\hline Treatment & Description of site-preparation operations \\
\hline \multicolumn{2}{|c|}{ No disturbance } \\
\hline TSMO & Original condition (without plantation) \\
\hline \multicolumn{2}{|c|}{ Slight disturbance } \\
\hline SMPC & No tillage and hole plantation with hole digger ( $60 \mathrm{~cm}$ depth) \\
\hline RCAV & Continuous subsoiling, using a covering shovel and plantation in the furrow (around $60 \mathrm{~cm}$ depth) \\
\hline \multicolumn{2}{|c|}{ Moderate disturbance } \\
\hline SRVC & $\begin{array}{l}\text { No previous subsoiling with furrow hillock surface soil with two plough passes and plantation in the hillock side } \\
\text { (around } 90 \mathrm{~cm} \text { depth) }\end{array}$ \\
\hline RLVC & $\begin{array}{l}\text { Subsoiling on planting row, followed by two plough passes, leaving furrow hillock surface soil and plantation in the } \\
\text { hillock side (around } 90 \mathrm{~cm} \text { depth) }\end{array}$ \\
\hline \multicolumn{2}{|c|}{ High disturbance } \\
\hline RCVC & $\begin{array}{l}\text { Continuous subsoiling, followed by two plough passes, leaving furrow hillock surface soil and plantation in the hillock } \\
\text { side (around } 90 \mathrm{~cm} \text { depth) }\end{array}$ \\
\hline RCLC & Continuous subsoiling followed by continuous ploughing and plantation in the furrow (around $90 \mathrm{~cm}$ depth) \\
\hline
\end{tabular}
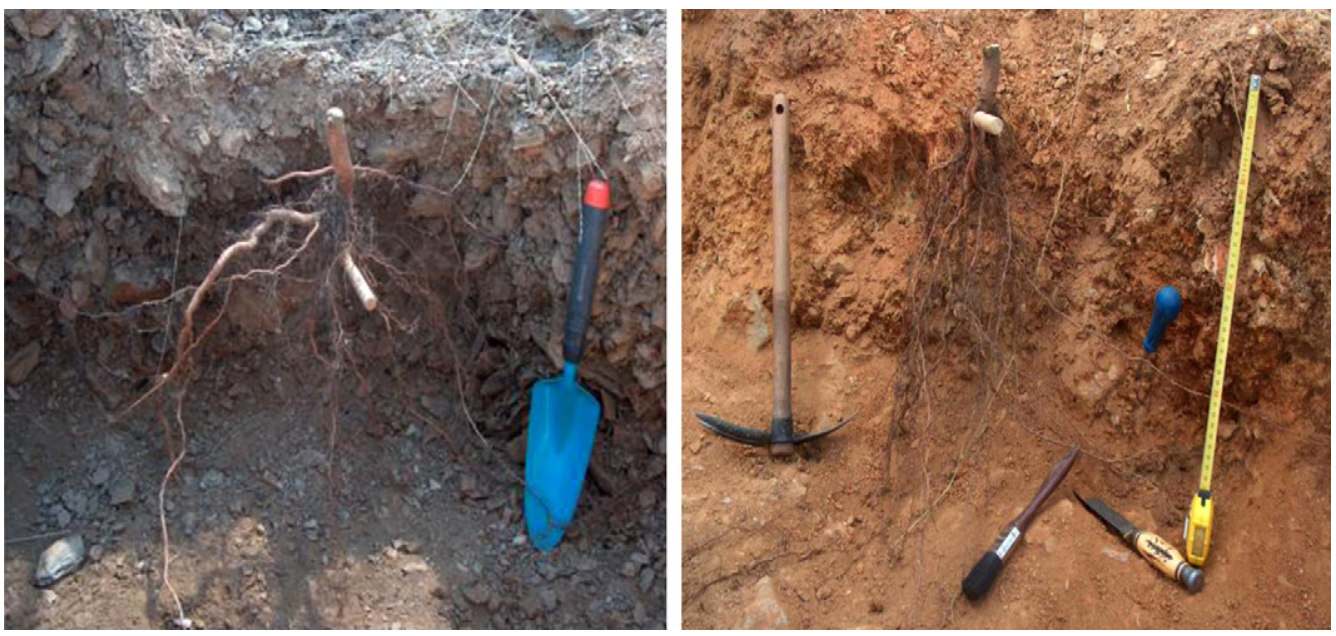

Fig. 3. Examples of root systems observed two years after plantation, in species CS and PM.

a complement to previous measurements, observations of the root system were also made following procedures described by Fonseca et al. (2005), as illustrated in Fig. 3.

One year after planting, six soil profiles per treatment were observed in the plantation line. Soil samples were taken at $0-20$, $20-40$ and $40-60 \mathrm{~cm}$ to assess the effects of site preparation on soil properties and possible relationships with plant response. Effective soil thickness, defined as the set of layers most explored by plant roots, was measured in each profile during soil profile description. In March 2004, the soil penetration resistance was determined using a penetrologger set with a cone of $1 \mathrm{~cm}^{2}$ and angle of $60^{\circ}$, to an $80 \mathrm{~cm}$ maximum depth, making up 30 measurements per treatment.

Statistical analysis of data comprised one-way ANOVA and multiple comparison of averages (Tukey, 5\%), performed to assess the significance of treatment effects on results. Mortality data were transformed ( 2 arc sine $\sqrt{x}, x$ being the mortality expressed as percentage of the total number of plants in each plot) prior to ANOVA (Dagnelie, 1973). Simple correlation analyses were applied to estimate and test hypothesized relationships between variables.

\section{Results and discussion}

\subsection{Soil characteristics}

Results presented in this sub-section concern soil properties associated with the two main determinants of plant survival and growth in young forest stands: (i) root expansion allowed within soil thickness, which determines access to soil-borne resources required for plant growth, as water and nutrients; (ii) fertility status in layers most relevant for soil biological activity identified by selected chemical properties in surface soil.

The soil effective thickness (rooting depth) is higher in treatments with moderate and intensive site preparation than in the remainder ones (Fig. 4). The treatments SRVC, RLVC and RCLC, when compared with the original soil (TSMO), show the greatest increase in soil depth, with increments from 30 to $40 \mathrm{~cm}$ along the planta-

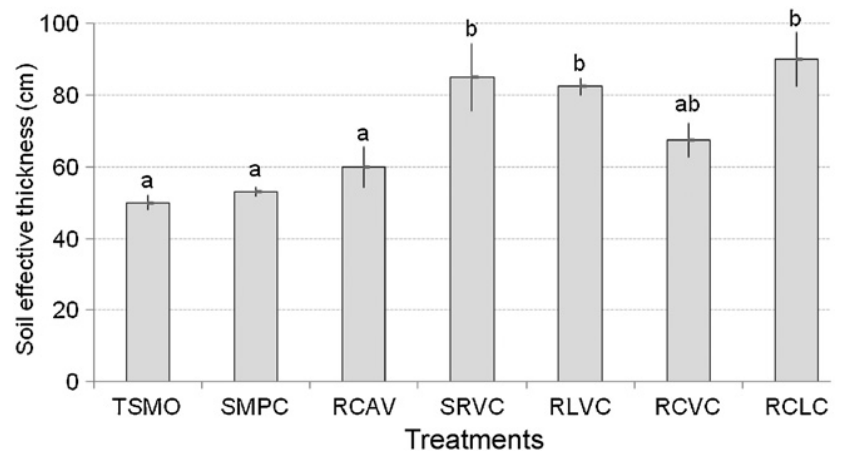

Fig. 4. Means and standart errors of soil effective thickness one year after site preparation. For treatments, averages with the same letter are not significantly different $(P<0.05)$. 


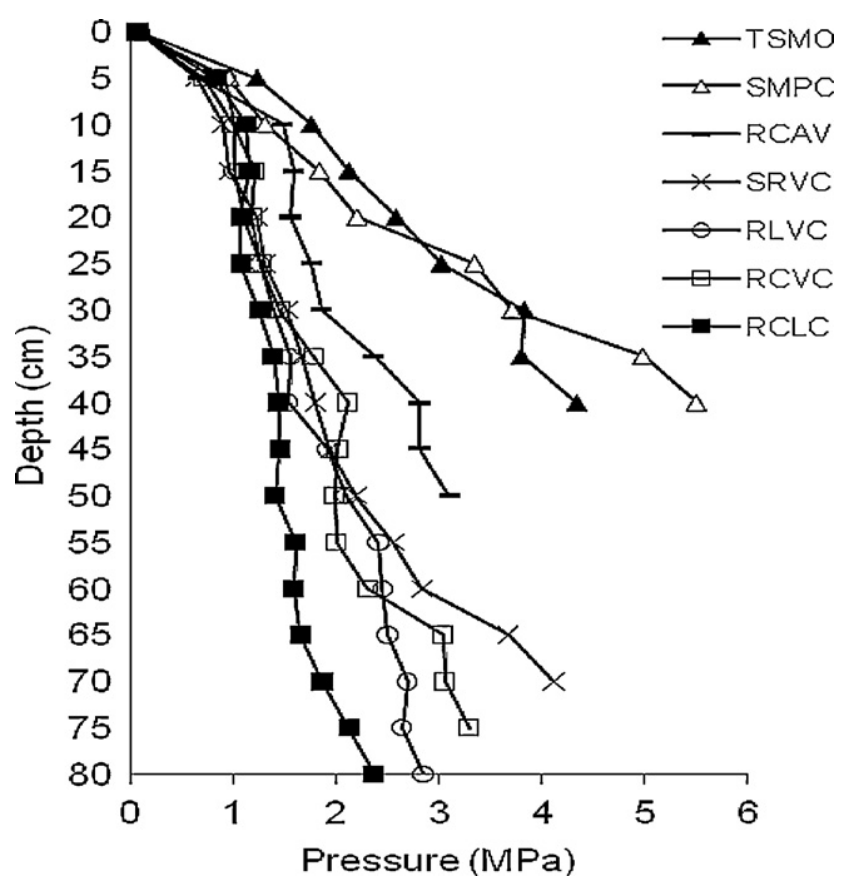

Fig. 5. Average soil penetration resistance in March 2004 (two years after site preparation), according to the treatments.

tion row. In slight soil disturbance treatments (SMPC and RCAV), this effect was hardly noticeable. Also, treatments with slight soil disturbance and the original soil (TSMO) together show the highest soil penetration resistance whereas the most intensive one (RCLC), presents the lowest among all treatments. Treatments with furrow hillock surface soil (SRVC, RLVC and RCVC) show intermediate values of soil resistance to penetration (Fig. 5). Thus, intensification of site preparation contributed to the increase of soil depth and decreased soil strength, factors that promote root expansion and development, gas exchange and water infiltration and redistribution in the profile, contributing to plantations' success. Soil penetration resistance may be an appropriate index to evaluate the influence of soil density in the distribution and development of root systems (Schoenholtz et al., 2000). Relationships between root growth and soil penetration resistance are reported by several authors (Curt et al., 2001; Abu-Hamdeh, 2003; Fonseca et al., 2005; Carlson et al., 2006; Sánchez-Andrés et al., 2006).

Values of soil organic carbon, total nitrogen, phosphorus extractable (P Olsen), sum of exchangeable bases and $\mathrm{pH}\left(\mathrm{H}_{2} \mathrm{O}\right)$ are depicted in Table 2. Results show that, when compared with the original soil (TSMO), soil organic carbon and total nitrogen decrease significantly in treatments with moderate and high soil disturbance (SRVC, RLVC, RCVC and RCLC), while sum of exchangeable bases increase, but only significantly in SRVC. Values of $\mathrm{pH}\left(\mathrm{H}_{2} \mathrm{O}\right)$ did not vary significantly with treatment (4.8-5.1).
Typically, site preparation favors the mixing of organic matter and mineral soil, which stimulates bacterial population growth and consequent mineralization of organic matter (Madeira et al., 1989; Johansson, 1994; Hussain et al., 1999; Islam and Weil, 2000), leading to loss or transfer of nutrients, particularly carbon and nitrogen (Islam and Weil, 2000; Piatek et al., 2003). The reduction in soil nutrient levels can affect the plantations success, even though this is not a factor as critical as soil moisture content and aeration (Archibold et al., 2000). In spite of the changes in carbon and nitrogen induced by site preparation techniques, Dick et al. (1998) report that the largest changes in organic matter content occur during the first five years after site preparation, with little variation beyond that period.

\subsection{Species mortality}

Table 3 shows that the SMPC and RCAV treatments, with less intense soil tillage, have mortality of almost $90 \%$ for both species, $P M$ and CS. In the other treatments mortality was generally lower than 50\%, especially in SRVC and RLVC, but with higher values in the case of PM. On the other hand, almost all the mortality occurred during the dry season after plantation (Fig. 6), which underlines the high susceptibility of recently planted species during this period, corroborating results reported in literature (e.g., Cogliastro et al., 1997; Bocio et al., 2004).

The mortality before the dry season (bds) on the year of plantation does not generally show significant differences among treatments, which seems to indicate a high genetic homogeneity of seedlings. After the dry season (ads), a high mortality was observed with clear differences between the SMPC and RCAV plots (slight soil disturbance) and the other treatments. Also in 2003 and 2004, mortality was observed only during the dry season, which emphasizes the effect of water deficit in the summer months, in soils under Mediterranean conditions. Similar results were obtained by Bocio et al. (2004), in similar climatic conditions, with species Quercus rotundifolia. In 2005, despite the severe/extreme drought, recorded at National level, there was no mortality, which may suggest that three years after installation, the plants were adapted to edaphoclimatic conditions of the experimental area. Gomes (1982) notes that mortality rate may be an indicator of species adaptation to the environmental conditions.

Taking into account the climatic characteristics of the study area (high summer water deficit), soil effective thickness proved to be a property determinant of survival, with good correlation between both variables in the years 2002, 2003 and 2004 (Table 4). Moreover, in plots in which soil effective thickness did not exceed $60 \mathrm{~cm}$, the mortality was above $95 \%$ for both species. Querejeta et al. (2001) reported that under severe weather conditions, the rooting depth is crucial for survival and growth of forest species in stands newly installed. As expected, and confirmed by the results of other authors, water deficit has a remarkable effect on young plantations which have their root system at the surface layers and thus, are more sus-

Table 2

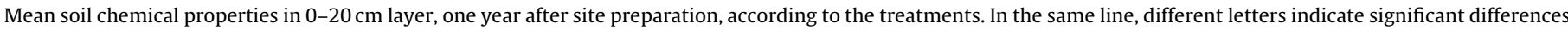
between treatment means $(P<0.05)$.

\begin{tabular}{|c|c|c|c|c|c|c|c|}
\hline \multirow[t]{2}{*}{ Parameter } & \multicolumn{7}{|c|}{ Treatments } \\
\hline & TSMO & SMPC & RCAV & SRVC & RLVC & $\mathrm{RCVC}$ & RCLC \\
\hline Organic C ( $\left.\mathrm{g} \mathrm{kg}^{-1}\right)$ & $11.4^{\mathrm{b}}$ & $11.1^{\mathrm{b}}$ & $8.3^{\mathrm{ab}}$ & $4.7^{\mathrm{a}}$ & $5.9^{\mathrm{a}}$ & $7.4^{\mathrm{a}}$ & $6.0^{\mathrm{a}}$ \\
\hline Total $\mathrm{N}\left(\mathrm{g} \mathrm{kg}^{-1}\right)$ & $0.70^{\mathrm{b}}$ & $0.82^{\mathrm{b}}$ & $0.65^{\mathrm{ab}}$ & $0.46^{\mathrm{a}}$ & $0.57^{\mathrm{a}}$ & $0.59^{\mathrm{a}}$ & $0.47^{\mathrm{a}}$ \\
\hline P Olsen ( $\mathrm{mg} \mathrm{kg}^{-1}$ ) & $28^{\mathrm{ab}}$ & $47^{\mathrm{b}}$ & $40^{\mathrm{ab}}$ & $24^{\mathrm{a}}$ & $16^{\mathrm{ab}}$ & $32^{\mathrm{ab}}$ & $35^{\mathrm{ab}}$ \\
\hline Sum exchange bases $\left(\mathrm{cmol}_{\mathrm{C}} \mathrm{kg}^{-1}\right)$ & $1.5^{\mathrm{a}}$ & $1.4^{\mathrm{a}}$ & $1.8^{\mathrm{a}}$ & $3.3^{\mathrm{b}}$ & $1.6^{\mathrm{a}}$ & $1.2^{\mathrm{a}}$ & $2.3^{\mathrm{ab}}$ \\
\hline $\mathrm{pH}\left(\mathrm{H}_{2} \mathrm{O}\right)$ & $5.1^{\mathrm{a}}$ & $4.9^{\mathrm{a}}$ & $5.1^{\mathrm{a}}$ & $5.0^{\mathrm{a}}$ & $4.9^{\mathrm{a}}$ & $4.8^{\mathrm{a}}$ & $5.0^{\mathrm{a}}$ \\
\hline
\end{tabular}


Table 3

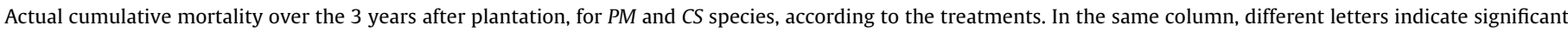
differences between treatment means $(P<0.05)$.

\begin{tabular}{|c|c|c|c|c|c|c|}
\hline \multirow[t]{3}{*}{ Treatment } & \multicolumn{3}{|c|}{ Pseudotsuga menziesii (PM) } & \multicolumn{3}{|c|}{ Castanea sativa (CS) } \\
\hline & 2002 & 2003 & 2004 & 2002 & 2003 & 2004 \\
\hline & \multicolumn{3}{|c|}{ Mean \pm standard error } & \multicolumn{3}{|c|}{ Mean \pm standard error } \\
\hline SMPC & $97.3 \pm 2.7^{a}$ & $98.7 \pm 1.3^{\mathrm{a}}$ & $98.7 \pm 1.3^{\mathrm{a}}$ & $98.7 \pm 1.3^{\mathrm{a}}$ & $98.7 \pm 1.3^{\mathrm{a}}$ & $98.7 \pm 1.3^{\mathrm{a}}$ \\
\hline RCAV & $87.0 \pm 13.0^{\mathrm{a}}$ & $87.0 \pm 13.0^{\mathrm{a}}$ & $87.0 \pm 13.0^{\mathrm{a}}$ & $88.7 \pm 5.7^{a}$ & $90.4 \pm 5.3^{a}$ & $90.4 \pm 5.3^{a}$ \\
\hline SRVC & $32.2 \pm 6.1^{\mathrm{b}}$ & $36.6 \pm 7.8^{\mathrm{b}}$ & $42.4 \pm 9.8^{\mathrm{b}}$ & $19.5 \pm 10.2^{b}$ & $29.5 \pm 20.2^{b}$ & $32.7 \pm 18.9^{b}$ \\
\hline RLVC & $34.2 \pm 4.8^{\mathrm{b}}$ & $43.2 \pm 2.3^{b}$ & $43.2 \pm 2.3^{b}$ & $19.6 \pm 3.9^{\mathrm{b}}$ & $19.6 \pm 3.9^{\mathrm{b}}$ & $19.6 \pm 3.9^{\mathrm{b}}$ \\
\hline RCVC & $51.2 \pm 8.4^{\mathrm{b}}$ & $56.9 \pm 8.3^{b}$ & $58.2 \pm 8.0^{\mathrm{b}}$ & $16.5 \pm 9.2^{\mathrm{b}}$ & $19.7 \pm 3.6^{\mathrm{b}}$ & $24.4 \pm 6.2^{\mathrm{b}}$ \\
\hline RCLC & $48.0 \pm 7.3^{b}$ & $48.0 \pm 7.3^{\mathrm{b}}$ & $48.0 \pm 7.3^{b}$ & $44.8 \pm 9.2^{b}$ & $47.4 \pm 8.9^{b}$ & $48.8 \pm 9.0^{\mathrm{b}}$ \\
\hline
\end{tabular}
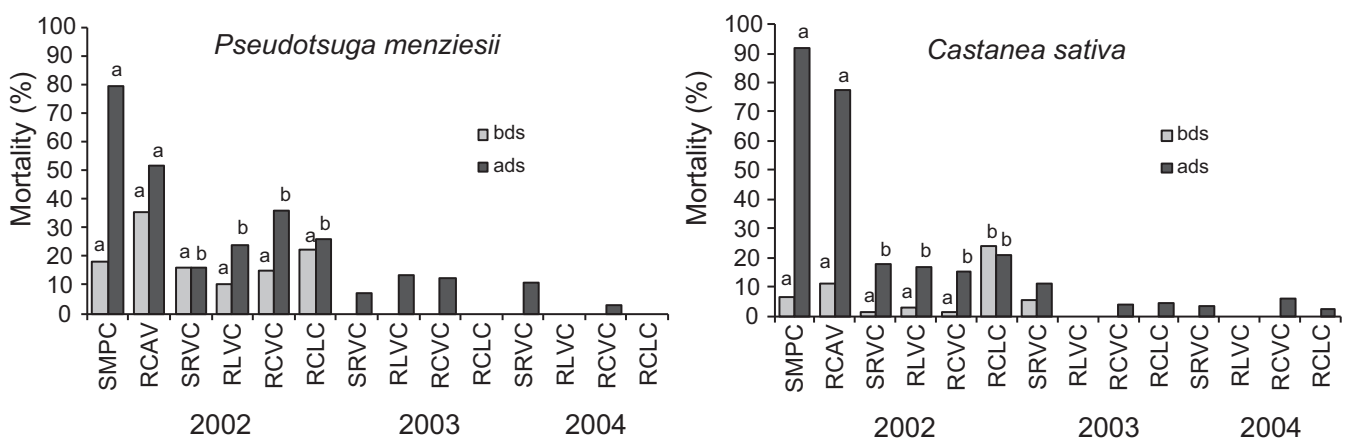

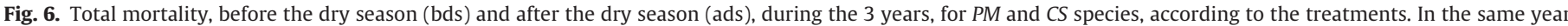
and for the same period (bds or ads), different letters indicate significant differences between treatment means $(P<0.05)$.

ceptible to the Mediterranean type of climate (Alves, 1988; Fernandes and Fernandes, 1998; Kanegae et al., 2000; Bocio et al., 2004).

For a better understanding of the plant behavior, the root system was observed. On SMPC plots there was generally a compact layer beneath $25-30 \mathrm{~cm}$ depth, which made it difficult for root penetration, as confirmed by direct observation of root systems configuration. On RCAV plots a large amount of coarse fragments was observed in the soil profile at about $30 \mathrm{~cm}$ or deeper, due to the effect of the ripper, which broke the parent material during subsoiling when site preparation was performed, but did not promote a good mixture with fine material. This insufficient mixture of coarse and fine materials was unfavorable for root growth, because of the poor plant/soil interface that prevails under these circumstances.

\subsection{Species growth}

Results concerning plant growth as affected by site preparation technique are presented in Tables 5-7 and in Fig. 7. The number of plants actually measured during the four growing seasons decreased from the initial 72 per treatment at plantation and 30-53, depending on treatment and species,

Table 4

Coefficients and significance of the correlation between soil effective thickness and mortality ( $n=18$ in each case) in the years 2002, 2003 and 2004 for $P M$ and CS species $\left({ }^{*} 0.05>P>0.01 ;{ }^{* *} 0.01>P>0.001 ;{ }^{* * *} P<0.001\right)$.

\begin{tabular}{lcll}
\hline Species & \multicolumn{2}{l}{ Years } & \\
\cline { 2 - 4 } & 2002 & 2003 & 2004 \\
\hline$P M$ & $0.843^{* * *}$ & $0.863^{* * *}$ & $0.868^{* * *}$ \\
$C S$ & $0.662^{* *}$ & $0.643^{* *}$ & $0.661^{* *}$ \\
\hline
\end{tabular}

42 months later. However, it should be stressed that statistical computations were done considering height and diameter of the same individual plants in each treatment and measurement date, meaning a number of plants falling within the range mentioned above and depicted in Table 7. Comparable sample sizes are found in literature reporting similar studies (30 plants in Martins and Pinto, 2004; 60 plants in Madeira et al., 1989).

The influence of the treatments on growth of PM and CS (height and diameter) is shown in Table 5. For plant height, there are significant differences between treatments after 24 months in CS and 39 months in PM. However, from 24 months on, PM species shows sensible plant growth increase in RCLC when compared with the remainder treatments. As regards the diameter increase, the effect of the treatments is clear for both species but more delayed for PM. Height growth occurred only in spring (24-27 and 36-39 months) whereas the diameter growth occurred in spring and summer (27-30 and 39-42 months) (Table 5). This growth pattern is consistent with the strategy of adaptation to summer water deficits (Danner and Knapp, 2001). The mean increase in both height and diameter for each one of the species shows a very similar trend, but the response of the two species is completely different (Fig. 7). In fact, PM species shows a much steadier increase in height and diameter with time when compared with that of CS.

The relationship between soil effective thickness and plant growth, in general, strengthens with time after plantation (Table 6). This highlights the importance of creating conditions for an increased exploitation of soil volume by roots in the early years of plant establishment, as reported by several authors (Varelides and Kritikos, 1995; Querejeta et al., 2001; Abu-Hamdeh, 2003). Table 7 shows that there is a close and significant relation between the height of plants at plantation and that at 12 months, in both species, and the same 
Table 5

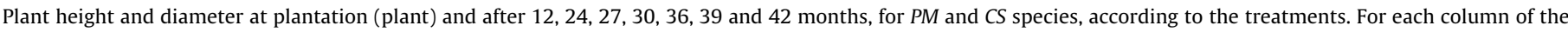
same species and variable, different letters indicate significant differences between treatment means $(P<0.05)$.

\begin{tabular}{|c|c|c|c|c|c|c|c|c|c|}
\hline \multirow[t]{2}{*}{ Species } & \multirow[t]{2}{*}{ Treat } & \multirow[t]{2}{*}{ Plantation } & \multicolumn{7}{|c|}{ Time (months) } \\
\hline & & & 12 & 24 & 27 & 30 & 36 & 39 & 42 \\
\hline \multicolumn{10}{|c|}{ Height (mean \pm standard error $(\mathrm{cm})$ ) } \\
\hline \multirow[t]{4}{*}{$P M$} & SRVC & $8.2 \pm 0.6^{\mathrm{a}}$ & $25.0 \pm 1.5^{\mathrm{a}}$ & $47.5 \pm 2.9^{\mathrm{a}}$ & $77.3 \pm 4.2^{\mathrm{a}}$ & $78.1 \pm 4.2^{\mathrm{a}}$ & $80.1 \pm 4.5^{\mathrm{a}}$ & $125.5 \pm 6.2^{\mathrm{ab}}$ & $126.8 \pm 6.3^{\mathrm{ab}}$ \\
\hline & RLVC & $5.8 \pm 0.5^{\mathrm{a}}$ & $21.3 \pm 0.9^{a}$ & $43.9 \pm 2.2^{\mathrm{a}}$ & $72.1 \pm 3.6^{a}$ & $72.9 \pm 3.6^{\mathrm{a}}$ & $74.5 \pm 4.0^{\mathrm{a}}$ & $119.4 \pm 5.4^{\mathrm{ab}}$ & $122.5 \pm 5.6^{\mathrm{ab}}$ \\
\hline & RCVC & $7.7 \pm 0.5^{\mathrm{a}}$ & $23.4 \pm 1.3^{\mathrm{a}}$ & $42.6 \pm 2.7^{\mathrm{a}}$ & $68.2 \pm 4.5^{\mathrm{a}}$ & $68.6 \pm 4.4^{\mathrm{a}}$ & $68.6 \pm 4.6^{\mathrm{a}}$ & $106.5 \pm 6.3^{\mathrm{b}}$ & $114.1 \pm 6.6^{\mathrm{b}}$ \\
\hline & RCLC & $8.5 \pm 0.7^{\mathrm{a}}$ & $24.3 \pm 1.2^{\mathrm{a}}$ & $49.5 \pm 3.1^{\mathrm{a}}$ & $86.0 \pm 5.0^{\mathrm{a}}$ & $87.5 \pm 5.1^{\mathrm{a}}$ & $88.6 \pm 5.7^{a}$ & $144.5 \pm 7.8^{\mathrm{a}}$ & $146.1 \pm 7.9^{a}$ \\
\hline \multirow[t]{4}{*}{$C S$} & SRVC & $35.8 \pm 1.9^{\mathrm{a}}$ & $48.1 \pm 1.8^{\mathrm{a}}$ & $72.1 \pm 2.7^{\mathrm{ab}}$ & $96.7 \pm 4.4^{\mathrm{ab}}$ & $97.4 \pm 4.4^{\mathrm{ab}}$ & $99.8 \pm 4.3^{\mathrm{a}}$ & $118.6 \pm 6.3^{\mathrm{ab}}$ & $121.0 \pm 6.3^{\mathrm{ab}}$ \\
\hline & RLVC & $36.0 \pm 1.5^{\mathrm{a}}$ & $50.6 \pm 1.8^{\mathrm{a}}$ & $74.7 \pm 2.2^{\mathrm{a}}$ & $97.4 \pm 3.2^{\mathrm{a}}$ & $97.8 \pm 3.2^{\mathrm{a}}$ & $99.0 \pm 3.4^{\mathrm{ab}}$ & $123.1 \pm 4.5^{\mathrm{a}}$ & $125.2 \pm 4.6^{\mathrm{a}}$ \\
\hline & RCVC & $34.3 \pm 2.0^{\mathrm{a}}$ & $46.0 \pm 1.8^{\mathrm{a}}$ & $64.5 \pm 2.3^{\mathrm{b}}$ & $85.3 \pm 3.2^{b}$ & $85.6 \pm 3.2^{\mathrm{b}}$ & $86.4 \pm 3.2^{\mathrm{a}}$ & $106.3 \pm 4.1^{\mathrm{b}}$ & $106.9 \pm 4.1^{\mathrm{b}}$ \\
\hline & RCLC & $34.6 \pm 2.1^{\mathrm{a}}$ & $48.0 \pm 2.3^{\mathrm{a}}$ & $70.5 \pm 3.8^{\mathrm{ab}}$ & $100.4 \pm 5.2^{\mathrm{a}}$ & $100.8 \pm 5.3^{\mathrm{a}}$ & $102.9 \pm 5.9^{b}$ & $139.3 \pm 8.9^{\mathrm{a}}$ & $140.7 \pm 8.9^{\mathrm{a}}$ \\
\hline \multicolumn{10}{|c|}{ Diameter (mean \pm standard error $(\mathrm{mm})$ ) } \\
\hline \multirow[t]{4}{*}{$P M$} & SRVC & $2.1 \pm 0.1^{\mathrm{a}}$ & $7.3 \pm 0.4^{\mathrm{a}}$ & $14.0 \pm 0.7^{\mathrm{a}}$ & $18.2 \pm 0.9^{\mathrm{ab}}$ & $21.8 \pm 1.1^{\mathrm{ab}}$ & $22.8 \pm 1.2^{\mathrm{ab}}$ & $30.3 \pm 1.6^{\mathrm{ab}}$ & $32.4 \pm 1.7^{\mathrm{ab}}$ \\
\hline & RLVC & $2.1 \pm 0.1^{\mathrm{a}}$ & $6.5 \pm 0.4^{\mathrm{a}}$ & $12.7 \pm 0.6^{\mathrm{a}}$ & $16.1 \pm 0.8^{\mathrm{b}}$ & $19.2 \pm 0.9^{b}$ & $20.1 \pm 1.0^{\mathrm{b}}$ & $28.2 \pm 1.4^{\mathrm{b}}$ & $30.8 \pm 1.6^{\mathrm{b}}$ \\
\hline & RCVC & $2.0 \pm 0.1^{\mathrm{a}}$ & $6.6 \pm 0.4^{a}$ & $13.0 \pm 0.8^{\mathrm{a}}$ & $15.9 \pm 1.0^{\mathrm{b}}$ & $19.6 \pm 1.2^{\mathrm{b}}$ & $20.0 \pm 1.3^{b}$ & $26.0 \pm 1.6^{\mathrm{b}}$ & $29.8 \pm 1.7^{b}$ \\
\hline & RCLC & $1.9 \pm 0.1^{\mathrm{a}}$ & $7.4 \pm 0.5^{\mathrm{a}}$ & $15.2 \pm 0.9^{\mathrm{a}}$ & $20.6 \pm 1.1^{\mathrm{a}}$ & $25.5 \pm 1.4^{\mathrm{a}}$ & $26.5 \pm 1.6^{\mathrm{a}}$ & $35.8 \pm 1.9^{\mathrm{a}}$ & $37.8 \pm 2.0^{\mathrm{a}}$ \\
\hline \multirow[t]{4}{*}{$C S$} & SRVC & $6.7 \pm 0.2^{\mathrm{a}}$ & $11.6 \pm 0.4^{\mathrm{a}}$ & $20.0 \pm 0.8^{\mathrm{ab}}$ & $24.6 \pm 1.2^{\mathrm{a}}$ & $27.9 \pm 1.4^{\mathrm{ab}}$ & $29.1 \pm 1.4^{\mathrm{a}}$ & $35.8 \pm 1.9^{a}$ & $36.2 \pm 1.9^{a}$ \\
\hline & RLVC & $6.6 \pm 0.2^{\mathrm{a}}$ & $11.6 \pm 0.4^{\mathrm{a}}$ & $19.7 \pm 0.7^{\mathrm{a}}$ & $23.9 \pm 0.9^{\mathrm{a}}$ & $27.0 \pm 1.1^{\mathrm{a}}$ & $27.7 \pm 1.1^{\mathrm{a}}$ & $34.1 \pm 1.4^{\mathrm{a}}$ & $35.3 \pm 1.5^{a}$ \\
\hline & RCVC & $6.0 \pm 0.2^{\mathrm{a}}$ & $10.7 \pm 0.3^{a}$ & $17.1 \pm 0.7^{\mathrm{b}}$ & $20.5 \pm 0.9^{\mathrm{b}}$ & $23.3 \pm 1.0^{\mathrm{b}}$ & $24.1 \pm 1.0^{\mathrm{b}}$ & $29.3 \pm 1.3^{\mathrm{b}}$ & $30.4 \pm 1.4^{\mathrm{b}}$ \\
\hline & RCLC & $6.6 \pm 0.3^{\mathrm{a}}$ & $11.7 \pm 0.5^{\mathrm{a}}$ & $19.8 \pm 1.0^{\mathrm{a}}$ & $25.1 \pm 1.3^{\mathrm{a}}$ & $29.1 \pm 1.6^{a}$ & $30.7 \pm 1.8^{\mathrm{a}}$ & $38.1 \pm 2.3^{\mathrm{a}}$ & $40.0 \pm 2.5^{a}$ \\
\hline
\end{tabular}

Table 6

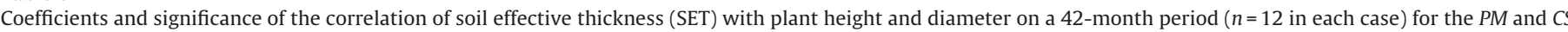
species $\left({ }^{*} 0.05>P>0.01 ;{ }^{* *} 0.01>P>0.001 ;{ }^{* * *} P<0.001\right)$.

\begin{tabular}{|c|c|c|c|c|}
\hline \multirow[t]{2}{*}{ Species } & \multicolumn{4}{|c|}{ Time after plantation } \\
\hline & 12 months & 24 months & 36 months & 42 months \\
\hline \multicolumn{5}{|c|}{ Correlation SET vs plant height } \\
\hline$P M$ & 0.354 & 0.440 & 0.530 & $0.575^{*}$ \\
\hline CS & 0.151 & 0.487 & $0.583^{*}$ & $0.594^{*}$ \\
\hline \multicolumn{5}{|c|}{ Correlation SET vs plant diameter } \\
\hline$P M$ & 0.422 & 0.346 & 0.462 & 0.469 \\
\hline CS & $0.753^{* *}$ & $0.715^{* *}$ & $0.634^{*}$ & $0.644^{*}$ \\
\hline
\end{tabular}

was observed in C. sativa for plant diameter, which seemingly reflects a high homogeneity of seedling material. Similar results were observed by Richter (1971) and cited by Carneiro (1995). During the two following growing seasons (12-24 and 24-36 months) this tendency decreased, emphasizing the growing influence of the environmental conditions with the age of plants.
In spite of the relationship found between treatments and plant growth, for the observed period it is not possible to define a general quantitative trend of growth based on the soil tillage intensity. Previous results under identical climatic conditions showed no significant differences on height and diameter growth for Robinia pseudoacacia (Martins and Pinto, 2004) and for Eucalyptus globulus (Madeira et al., 1989), due

Table 7

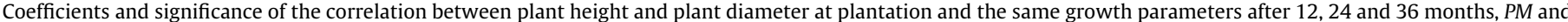
CS $\left({ }^{*} 0.05>P>0.01 ;{ }^{* *} 0.01>P>0.001 ;{ }^{* * *} P<0.001\right)$.

\begin{tabular}{|c|c|c|c|c|}
\hline \multirow[t]{2}{*}{ Species } & \multirow[t]{2}{*}{ Treatment $(n)$} & \multicolumn{3}{|c|}{ Time after plantation } \\
\hline & & 12 months & 24 months & 36 months \\
\hline \multicolumn{5}{|c|}{ Correlation of actual plant height with that at plantation } \\
\hline \multirow[t]{4}{*}{$P M$} & SRVC (40) & $0.495^{* *}$ & $0.366^{*}$ & 0.308 \\
\hline & RLVC (38) & $0.507^{* *}$ & 0.295 & 0.260 \\
\hline & RCVC (30) & $0.458^{*}$ & 0.256 & 0.307 \\
\hline & $\operatorname{RCLC}(37)$ & $0.520^{* * *}$ & 0.265 & 0.287 \\
\hline \multirow[t]{4}{*}{ CS } & SRVC (46) & $0.857^{* * *}$ & 0.250 & 0.036 \\
\hline & RLVC (53) & $0.662^{* * *}$ & 0.162 & 0.048 \\
\hline & RCVC (51) & $0.798^{* * *}$ & $0.301^{*}$ & 0.090 \\
\hline & RCLC (39) & $0.788^{* * *}$ & $0.461^{* *}$ & $0.424^{*}$ \\
\hline \multicolumn{5}{|c|}{ Correlation of actual plant diameter with that at plantation } \\
\hline \multirow[t]{4}{*}{$P M$} & SRVC (40) & 0.347 & 0.376 & 0.312 \\
\hline & RLVC (38) & 0.273 & 0.246 & 0.323 \\
\hline & RCVC (30) & $0.523^{* *}$ & $0.433^{*}$ & $0.407^{*}$ \\
\hline & RCLC (37) & 0.246 & 0.266 & 0.117 \\
\hline \multirow[t]{4}{*}{$C S$} & SRVC (46) & $0.582^{* * *}$ & 0.218 & 0.098 \\
\hline & RLVC (53) & $0.461^{* * *}$ & $0.378^{* *}$ & $0.389^{* *}$ \\
\hline & $\operatorname{RCVC}(51)$ & $0.332^{* * *}$ & 0.052 & 0.030 \\
\hline & RCLC (39) & $0.441^{* * *}$ & 0.285 & 0.226 \\
\hline
\end{tabular}



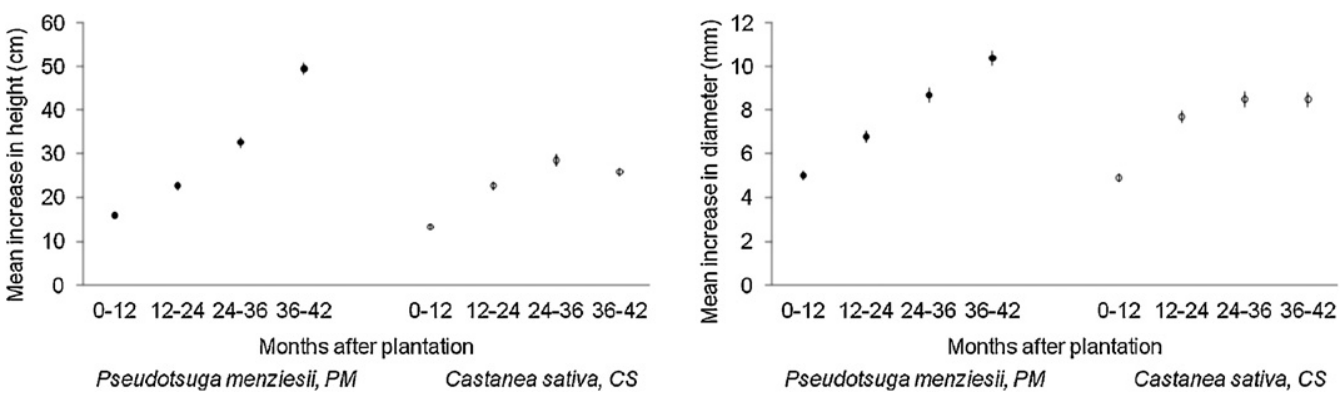

Fig. 7. Evolution of the plant height and diameter increments (mean \pm standard error), in the first four growing seasons, for $P M$ and $C S$ species.

to different soil preparation operations, 30 months after plantation.

\section{Conclusions}

Mortality after planting was affected by the soil preparation technique, showing a very high mortality on the less intense treatments for both species, which can be ascribed to the higher summer water deficit on those treatments. No clear differences were observed on plant mortality for the other site preparation operations. A relation between growing and treatment was found, but it is difficult to quantitatively define a trend according to soil disturbance intensity; a longer period of time is certainly necessary to experimentally reach that goal. Soil conditions determined by soil preparation techniques significantly influenced mortality and growth of forest species under test in the experiment reported, and this has a special emphasis in the case of soil effective thickness. The relationship between the plant growth and soil depth increased with time.

\section{Acknowledgments}

The authors wish to thank the Program AGRO measure 8.1, project Agro-156, which financially supported this study, the Regional Forestry Services, which were responsible by the mechanical soil operations and Mr. João Xavier, the owner of the experimental area, for his agreement on the establishment of the experiment.

\section{References}

Abu-Hamdeh, N.H., 2003. Soil compaction and root distribution for okra as affected by tillage and vehicle parameters. Soil \& Tillage Research 74, 25-35.

Agroconsultores, Coba, 1991. Carta dos Solos do Nordeste de Portugal. UTAD, Vila Real.

Alves, A.A.M., 1988. Técnicas de Produção Florestal. In: Fundamentos, Tipificação e Métodos, segunda ed. Instituto Nacional de Investigação Científica, Lisboa.

Archibold, O.W., Acton, C., Ripley, E.A., 2000. Effect of site preparation on soil properties and vegetation cover, and the growth and survival of white spruce (Picea glauca) seedlings, in Saskatchewan. Forest Ecology and Management 131, 127-141.

Bocio, I., Navarro, F.B., Ripoll, M.A., Jiménez, M.N., De Simón, E., 2004. Holm oak (Quercus rotundifolia Lam.) and Aleppo pine (Pinus halepensis Mill.) response to different soil preparation techniques applied to forestation in abandoned farmland. Annals of Forest Science 61, 171-178.

Burgess, D., Wetzel, S., 2000. Nutrient availability and regeneration response after partial cutting and site preparation in eastern white pine. Forest Ecology and Management 138, 249-261.

Canham, C.C., 1989. Different responses to gaps among shade-tolerant tree species. Ecology 70, 560-562.

Carlson, C.A., Fox, T.R., Colbert, S.R., Kelting, D.L., Allen, H.L., Albaugh, T.J., 2006. Growth and survival of Pinus taeda in response to surface and subsurface tillage in the southeastern United States. Forest Ecology and Management 234, 209-217.

Carneiro, J.G.A., 1995. Produção e Controle de Qualidade de Mudas Florestais. Universidade Federal do Paraná, Curitiba, pp. 41-65.

Cogliastro, A., Gagnon, D., Bouchard, A., 1997. Experimental determination of soil characteristics optimal for the growth of ten hardwoods planted on abandoned farmland. Forest Ecology and Management 96, 49-63.
Costa, J.C., Aguiar, C., Capelo, J.H., Neto, C., 1998. Aproximação à biogeografia de Portugal Continental. Quercetea, p. 56.

Curt, T., Lucot, E., Bouchaud, M., 2001. Douglas-fir root biomass and rooting profile in relation to soils in a mid-elevation area (Beaujolaia Mounts, France). Plant and Soil 233, 109-125.

Daget, P., 1977. Le bioclimat mediterranean: characteres généraux, modes de caractérisation. Vegetatio 34, 1-20.

Dagnelie, P., 1973. Estatística: Teoria e Métodos, vol. 2. Publicações Europa-América, Mem Martins, Portugal.

Danner, B.T., Knapp, 2001. Growth dynamics of oak seedlings (Quercus macrocarpa Michx. and Quercus muhlenbergii Engelm.) from gallery forests: implications for forest expansion into grasslands. Trees 15, 271-277.

Dick, W.A., Blevins, R.L., Frye, W.W., Peters, S.E., Christenson, D.R., Pierce, F.J., Vitosh, M.L., 1998. Impacts of agricultural management practices on $C$ sequestration in forest-derived soils of the eastern Corn Belt. Soil \& Tillage Research 47, 235-244.

FAO/UNESCO, 1987. Soil map of the world. Revised legend. Amended fourth draft. World Soil Resources Report, vol. 60. FAO, Rome.

Fernandes, J.A.P., Fernandes, H.M.F., 1998. Ensaio de diferentes graus de mobilização em plantações de Pinus pinaster Aiton. Revista Florestal XI (2), 56-62.

Fonseca, F., 2005. Técnicas de preparação do terreno em sistemas florestais: implicações no solo e no comportamento das plantas. Doctoral Thesis. Universidade de Trás-os-Montes e Alto Douro, Vila Real.

Fonseca, F., Martins, A., Nogueira, C., Figueiredo, T., Guerra, A., 2005. Distribuição e desenvolvimento do sistema radicular em povoamentos jovens de Castanea sativa e Pseudotsuga menziesii. In: Silva, R., Páscoa, F. (Eds.), Actas das Comunicações do $5^{\circ}$ Congresso Florestal Nacional. , p. 8 (Viseu).

Fisher, R., Binkley, D., 2000. Ecology and Management of Forest Soils. John Wiley \& Sons, Inc., NY, pp. 489.

Gomes, A.L., 1982. Preliminares do melhoramento florestal na zona norte do país. In: Ensaios juvenis de algumas essências. UTAD, Vila Real.

Hussain, I., Olson, K.R., Wander, M.M., Karlen, D.L., 1999. Adaptation of soil quality indices and application to three tillage systems in southern Illinois. Soil \& Tillage Research 50, 237-249.

INMG, 1991. Normais Climatológicas da Região de "Trás-os-Montes e Alto Douro" e "Beira Interior" Correspondentes a 1951-1980. Fascículo XLIX, vol. 3 (Lisboa).

Islam, K.R., Weil, R.R., 2000. Land use effects on soil quality in a tropical forest ecosystem of Bangladesh. Agriculture, Ecosystems and Environment 79, 9-16.

Johansson, M.B., 1994. The influence of soil scarification on the turn-over rate of slash needles and nutrient release. Scandinavian Journal of Forest Research 9 , 170-179.

Kanegae, M.F., Braz, V., Franco, A.C., 2000. Efeitos da seca sazonal e disponibilidade de luz na sobrevivência e crescimento de Bowdichia virgilioides em duas fitofisionomias típicas dos cerrados do Brasil Central. Revista Brasileira de Botany 23 (4), 459-468.

Lieberman, M., Lieberman, D., Peralta, R., 1989. Forests are not just swiss cheese: canopy stereogeometry of non-gaps in tropical forests. Ecology 70, 550-552.

Madeira, M.A.V., Melo, G.F., Alexandre, C.A., Steen, E., 1989. Effects of deep ploughing and superficial disc harrowing on physical and chemical soil properties and biomass in a new plantation of Eucalyptus globulus. Soil \& Tillage Research 14, 163-175.

Martins, A., Pinto, M.G., 2004. Efeitos da Ripagem Localizada Versus Ripagem Contínua nas Propriedades do Solo e na Resposta das Plantas em Novos Povoamentos Florestais. Silva Lusitana 12 (2), 191-202.

McLaughlin, J.W., Gale, M.R., Jurgensen, F., Trettin, C.C., 2000. Soil organic matter and nitrogen cycling in response to harvesting, mechanical site preparation, and fertilization in a wetland with a mineral substrate. Forest Ecology and Management 129, 7-23.

Ojasvi, P.R., Goyal, R.K., Gupta, 1999. The micro-catchment water harvesting technique for the plantation of jujube (Zizyphus mauritiana) in an agroforestry system under arid conditions. Agricultural Water Management 41, 139-147.

Piatek, K.B., Harrington, C.A., Debell, D.S., 2003. Site preparation effects on 20 year survival and growth of Douglas-fir (Pseudotsuga menziesii) and on selected soil properties. Western Journal of Applied Forestry 18, 44-51.

Querejeta, J.I., Roldán, A., Albadalejo, J., Castilllo, V., 2001. Soil water availability improved by site preparation in a Pinus halepensis afforestation under semiarid climate. Forest Ecology and Management 149, 115-128.

Rey, J.M., 1998. Growth and survival in Quercus ílex L. seedlings after irrigation and artificial shading on Mediterranean set-side agricultural land. Annals of Forest Science 55, 801-807. 
Ribeiro, O., 1986. Portugal o Mediterrâneo e o Atlântico. Livraria Sá da Costa Editora, Lisboa.

Sánchez-Andrés, R., Sánchez-Carrillo, S., Benítez, M., Sánchez-López, A., 2006. Tillage induced differential morphometric responses and growth patterns in afforestation with Quercus ilex. Soil \& Tillage Research 90, 50-62.

Schoenholtz, S.H., Van Miegroet, H., Burger, J.A., 2000. A review chemical and physical properties as indicators of forest soil quality: challenges and opportunities. In: Boyle, J.R., Powers, R.F. (Eds.), Forest Soils and Ecosystems Sustainability. Elsevier, NY, pp. 335-356.
Varelides, C., Kritikos, T., 1995. Effect of site preparation intensity and fertilization on Pinus pinaster survival and height growth on three sites in northern Greece. Forest Ecology and Management 73, 111-115.

Wetzel, S., Burgess, D., 2001. Understory environment and vegetation response afte partial cutting and site preparation in Pinus strobus L. stands. Forest Ecology and Management 151, 43-59.

Worrell, R., Hampson, A., 1997. The influence of some forest operations on the sustainable management of forest soils - a review. Forestry 70 (1), 6185 . 